\title{
Was Adam Smith an economic geographer?
}

\author{
Stefanos Ioannou • Dariusz Wójcik (i)
}

Accepted: 23 August 2021 / Published online: 15 September 2021

(C) The Author(s) 2021

\begin{abstract}
Economic geographers typically associate Adam Smith with the pin factory, the division of labour, and the 'invisible hand' of the market. We show that a closer reading of The Wealth of Nations reveals a much richer and broader range of ideas, which we illustrate by focusing on six themes: methodology, the role of physical geography and land in development, urban scale, institutions, commercial centres, and financial geography. On commercial centres, for example, Smith offers a vivid elaboration of what causes a 'home bias' in international trade. Similarly, in a largely neglected part of the book, Smith offers a thorough set of reflections as to what turned Amsterdam into the leading financial centre of Europe during the seventeenth century and eighteenth centuries. Overall, we argue that in all these themes and across them, Smith offers insights valuable to contemporary economic geography, making the Wealth of Nations worthy a place in an anthology of the discipline.
\end{abstract}

S. Ioannou

Oxford Brookes Business School, Oxford Brookes

University, Oxford OX3 0BP, UK

e-mail: sioannou@brookes.ac.uk

D. Wójcik ( $\bowtie)$

School of Geography and the Environment, University of

Oxford, South Parks Road, Oxford OX1 3QY, UK

e-mail: dariusz.wojcik@ouce.ox.ac.uk
Keywords Adam smith - The wealth of nations Economic geography $\cdot$ Financial geography

JEL Classification $\mathrm{B} 12 \cdot \mathrm{B} 40 \cdot \mathrm{R} 10 \cdot \mathrm{O} 10$

\section{Introduction}

The title of this article is an intentional provocation. Adam Smith (1723-1790) was a moral philosopher and political economist, not an economic geographer. Neither economics nor geography existed as independent academic disciplines in the eighteenth century, and neither word appears in Smith's magnum opus The Wealth of Nations. Nevertheless, his work offers valuable insights to economic geography.

The way contemporary economic geographers engage with Smith's work is rather scant, indirect, and somewhat controversial. Textbooks usually refer to Smith when discussing the division of labour (Dicken \& Lloyd, 1990; Lee \& Willis, 1997), but Massey's Spatial Divisions of Labour (1984) never mentions him. Wood and Roberts (2011) remark that the German location theorist von Thünen admired Smith's work, while Coe et al. (2013) credit Smith for elevating the study of economy from the household to the national and international scale. For Walker (2020), however, "Smithian ideas infect theories of urban and economic geography" (25). 
Likewise, while one could expect much attention to Smith in the work of geographical economics (also known as New Economic Geography), as a field closer to economics than economic geography, the evidence suggests otherwise. Krugman (1991), for example, does not refer to Smith at all, while a textbook by Brakman et al. (2012) mentions him only once, when discussing the significance of coastal access and transportation costs. What makes this scant treatment even more surprising is that geographical economics often invokes Alfred Marshall, who considered Smith the Darwin of modern economics (Winch, 2004).

Sole exception to such overlook is, to the best of our knowledge, a handful of French works on history of space in economic thought. ${ }^{1}$ Most notably, Dockès (1969), dedicates a chapter on Smith's geography, highlighting the impact of space upon the division of labour, the spatial variegation of wages, profits, rents and prices, and the importance of physical geography in determining the size of the market, amongst other aspects. Ponsard $(1983,11)$ also offers a catalogue of spatial dimensions in Smith's thought, though without going into further depth in discussing them.

Overall, it seems that 250 years after the writing of The Wealth, most economic geographers see little need to read it, let alone read it closely. In this context, our objective is to delve into selected aspects of Smith's Wealth of Nations relevant to economic geography. We will start with a brief note on historical context. Next, we will discuss Smith's methodological approach and the significance of physical geography. Then we will examine the importance of urban scale in the development of markets, and the role of urban development in the advancement of legal institutions and democratic representation. We will finish with Smith's insights into the geography of commercial centres and reflections of interest to financial geography. Our mission is not to copy paste every relevant passage, but to distil and discuss some of the most representative parts of the text. ${ }^{2}$ While our discussion highlights some key aspects of Adam Smith's

\footnotetext{
1 We are grateful to an anonymous reviewer for pointing these out. The fact that such works, as for instance Dockès (1969), often remain untranslated, highlights an additional knowledge barrier.

${ }^{2}$ For our analysis we have used the 1976 Glasgow edition of the book (Smith 1976 [1776]). This is the version of the book to which all page numbers correspond. All extracts have been copied from the free online version available in marxists.org
}

economic theory, a detailed elaboration of the latter lies outside the scope of our article (for a summary see Roncaglia, 2005).

\section{Historical context}

Smith's lifetime coincided with the growth of commercial capitalism in Europe, and the beginning of the industrial revolution. His death fell just six years before the Boulton and Watt steam engine obtained a patent (Sutherland, 2008). He was a contemporary of the Scottish philosopher David Hume, with who he established a long-lasting friendship, and François Quesnay, the most prominent intellectual of the Physiocrats, who he met in Paris circa 1765 (Heilbroner, 1999).

Physiocrats and Mercantilists were the most notable schools of economic thought at the time of Smith's writing. Physiocrats maintained that all value stems from agriculture. Smith criticised this view, by putting labour at the epicentre of value creation, thus elevating the significance of industry and trade; though he still sided with the Physiocrats on the leading role of agriculture for national economic development (Dockès, 1969; Heilbroner, 1999; Roncaglia, 2005). He was even more critical of Mercantilists, and their view that state intervention is required for protecting domestic industry and exports against foreign competition. Being particularly influential in policy at the time of Smith, Mercantilism provided the intellectual ground for justifying import prohibitions and duties, export bounties, etc. These were precisely the policies Smith was set to deconstruct in the Wealth of Nations, viewing them as obstacles in the proper functioning of the market, and thus in the creation of wealth.

Historical context is also important for appreciating Smith's view on market and government. In Smith's time, most markets were still dominated by small production units, compared to nowadays, hence closer to the competitive market prototype (Heilbroner, 1999). His opposition to government intervention was particularly strong against policies guided by the lobbying of merchants and manufacturers (see, for

\footnotetext{
Footnote 2 continued

(see https://www.marxists.org/reference/archive/smith-adam/ works/wealth-of-nations/).
} 
example, chapters 2 and 3 of book 4). He acknowledged the need for government to finance public works and institutions beneficial to society and unprofitable to individual investors (book 5). In this context, he also advocated a public system of universal and compulsory elementary education, a highly progressive view for his time (Sutherland, 2008).

\section{Methodological approach}

While Smith was a philosopher, his approach to research should find much resonance among economic geographers. Smith was a great eclectic drawing upon the knowledge of all possible disciplines (Viner, 1927). Alfred Marshall (1920) acknowledges the genius of Smith as someone who synthesized and advanced the British and French knowledge of his times. His work puts much emphasis on induction, e.g. in his description of economic development over centuries informed by historical detail. According to Roncaglia (2005) Smith believed in the creation of theory rather than discovering theories and revealing the 'laws of nature'. He denied the idea of "a mathematical structure of reality" (ibid.: 120), and recognized the complexity of humans and their motivations.

His theory was based, at least partly, on direct observation of economic practices and interactions with practitioners. In the most famous passage on the pin factory in the Wealth he says "I have seen a small manufactory ..." (15). In Glasgow, he was a member of various clubs that attracted leaders of the mercantile community (Winch, 2004). Ross (1995) mentions that Smith learnt much from debating with merchants in Glasgow's Political Economy Club. He also corresponded with Henry Hope, a member of the family who founded and ran Amsterdam-based Hope \& Co., the leading bank of the eighteenth century. The Wealth was actually written on Smith's return from a threeyear voyage to France and Switzerland.

At the analytical level, a distinction that permeates the whole of the Wealth, and thus underpins his geographical approach, is that between the town and the country. Related, market forces for Smith always operate within specific sub-national geographies. Market equilibria- to the extent that they can be achieved- are spatially bounded, such that notable discrepancies can systematically occur in wages, profits, rents and prices, across different regions, cities, villages, or even parts of a city (Dockès, 1969). This is particularly so in the case of wages, as "it appears evidently from experience that a man is of all sorts of luggage the most difficult to be transported" (93).

\section{The role of physical geography}

A key aspect of Smith's economic analysis is the importance of location close to the sea, a navigable river or canal (see particularly chapter 3, book 1). Through reduction in transportation costs, such proximity allows a town to enhance the scale of its market, and thereby deepen its division of labour.

Proximity to waterways also facilitates international trade, which puts a city in an advantageous positioning vis-à-vis the rest of the country. The inhabitants of such cities "have a much wider range, and may draw from the most remote corners of the world" such that their city might "grow up to great wealth and splendor", while the rest of the country remains impoverished (405). Furthermore, location close to waterways encourages a city to direct a greater part of its annual product towards investment in commerce and manufacture, rather than immediate consumption, thus improving the city's productivity.

Smith recognised that access to waterways is also a matter of political geography. Using the Danube as an example, he notes that for a nation to truly enjoy the benefits of access to a river, the latter must not run into foreign territory before reaching the sea. In addition, Smith viewed proximity to waterways as a major factor behind the development of ancient civilisations in the Mediterranean basin and Eastern China. For the same reason, as noted by Mellinger et al. (2000), Smith was pessimistic about the prospects of inland Asia and Africa (on Smith and Asia also see Arrighi, 2007).

While Mellinger et al. (2000) claim that Smith was less aware of the effects of climate on economic performance, the word climate occurs in The Wealth 18 times, often next to soil, as a factor affecting agriculture, but also the working conditions of people. Climate and soil are actually mentioned as factors of economic growth on the very first page of the introduction. Similarly, the role of climate underpins his discussion of what gives a country a comparative advantage in international trade. In a rather sarcastic 
way, in the context of criticising import duties, Smith writes:

"By means of glasses, hotbeds, and hot walls, very good grapes can be raised in Scotland, and very good wine too can be made of them at about thirty times the expense for which at least equally good can be brought from foreign countries. Would it be a reasonable law to prohibit the importation of all foreign wines merely to encourage the making of claret and burgundy in Scotland?" (458).

Physical geography and land rent

Physical geography also exercises influence over the level of land rent. ${ }^{3}$ Smith notices three determining factors. One is fertility of the land. The second is land's precise location. All else the same, rent is to be higher in areas closer to towns, due to the lower transportation costs involved in carrying the agricultural produce into the market. ${ }^{4}$ Third is the type of produce of the land. According to Smith, land producing food is to yield the most stable rent revenue, due to the inelastic demand for food. Less stable, and more context-specific, is the rent of land yielding clothing and lodging materials. Such rent largely depends on location and market access: "A good stone quarry in the neighbourhood of London would afford a considerable rent. In many parts of Scotland and Wales it affords none." (179).

Food agriculture also forms the basis for all other categories of rent. Smith sees increase in productivity in food agriculture as the main means for freeing resources for satisfying other human wants, from clothing and housing, to ornaments and items of luxury; and correspondingly, for increasing the economic value of the land producing the materials required for producing such goods.

\footnotetext{
3 Although beyond the scope of our commentary, it is worth noting the existence of a long literature debating Smith's theory of rent, already from the time of Ricardo; see amongst others Samuelson (1978), Gee (1981), and Brewer (1995).

${ }^{4}$ Besides transportation costs, another factor lowering rents in remote areas for Adam Smith is the prevalence of higher profit rates, compared to profit rates in towns; we discuss this aspect in Sect. 5.
}

\section{The importance of the urban scale}

Central to Smith's work is the positive relationship between the division of labour and the scale of the market, which extends from domestic to international economy, informing Smith's theory of international trade (Scott, 1997). What has attracted less attention in economic geography, however, is the relationship he draws between the size of the cities and the scale of the market, the latter measured here in terms of urban population (Dockès, 1969). ${ }^{5}$ Smith writes about specific types of employment- offspring of the division of labour- which can only be found in great towns, such as the job of the porter, smith, carpenter and mason, which require settlements beyond a certain scale, greater, for instance, than the small villages of the Highlands of Scotland (31). In this context, he sees the market as an intrinsic feature of the urban space, rather than simply an abstract notion related to the forces of supply and demand (Sutherland, 2008).

Smith also relates urban scale to other economic phenomena, including the determination of profit and prices; the space it opens for wealth accumulation and speculation; favourable conditions it creates for business lobbying and networking; and the centripetal and centrifugal forces in urban development (see particularly chapter 10 , book 1$)^{6}$

For Smith the scale of a town or a city influences the rate of profit and the price of commodities. He distinguishes between the apparent, and the actual rate of profit; the difference representing the compensation attributed to the actual labour of the merchant. In a small town, the size of some businesses will be small, and hence, the share of the owners' own labour in the total revenue of their businesses will be larger than in a bigger town or city. On the other hand, the difference between the apparent profit of retail and

\footnotetext{
$\overline{5}$ Dockès (1969) remarks that Smith uses two different notions of scale of the market. In the context of proximity to the sea or river, and correspondingly the lowering of transportation costs, Smith's notion of scale relates with the reduced geographical distance between suppliers of goods and their demand outlets. In the relationship between size of cities and the scale of the market, on the other hand, Smith has the volume of consumers in mind, itself a function of the population.

${ }^{6}$ Stull (1986) also identifies fragments of the book in which Smith implicitly connects the urban scale with urban housing costs. A notable passage can be found in p. 134-5 where Smith comments on the high renting costs of London.
} 
wholesale trade will be much smaller in big cities: "Where ten thousand pounds can be employed in the grocery trade, the wages of the grocer's labour make but a very trifling addition to the real profits of so great a stock" (129). Given such tendency, goods will tend to be cheaper in big cities, or at least as cheap, compared to smaller towns and villages. The counterforce is what Smith calls prime cost, associated with the distance that needs to be covered for goods to reach the market.

Apart from affecting profit rates and prices, for Smith, urban scale also positively affects the space for wealth accumulation. Due to the limited size of the market, a merchant located in a village cannot expand his business much, despite the higher profit rate he might enjoy. The difference between the rate of profit and the volume of profits is crucial for understanding why, for Smith, capital does not flow towards areas with higher profit rates, despite being perfectly mobile in theory (Dockès, 1969). ${ }^{7}$

Furthermore, according to Smith, the scale of the market in a city enables a merchant to frequently switch between different trades, and act as a speculator:

"The speculative merchant exercises no one regular, established, or well-known branch of business. He is a corn merchant this year, and a wine merchant the next, and a sugar, tobacco, or tea merchant the year after [...] A bold adventurer may sometimes acquire a considerable fortune by two or three successful speculations; but is just as likely to lose one by two or three unsuccessful ones. This trade can be carried on nowhere but in great towns. It is only in places of the most extensive commerce and correspondence that the intelligence requisite for it can be had." (130-1).

Smith was acutely aware of the dangers of business lobbying, referring to the merchants and manufacturers who "have generally an interest to deceive and even to oppress the public" (267) by narrowing competition and controlling prices. He relates the problem to urban scale, portraying large towns as a fertile ground for their inhabitants (including traders

\footnotetext{
${ }^{7}$ Dockès also observes that when extrapolated to the international plane, Smith's thinking also explains systematic differences between the profit rates of different nations.
}

and artisans) to combine and establish cartel agreements, thereby augmenting their incomes beyond what they would normally earn-in stark contrast to the inhabitants of the country who "dispersed in distant places, cannot easily combine together." (143). As a result, the city comes to exploit the countryside, charging artificially high prices for its exports of manufactured goods.

Given the advantages of the town, Smith observes that much more people make a fortune in a town than in the countryside. Capital and labour "naturally seek the most advantageous employment. They naturally, therefore, resort as much as they can to the town, and desert the country." (142). In this vein, Smith reflects on the centripetal forces behind urbanisation, and agglomeration economies (e.g. Scott, 1986). As Munck put it (2016: 812): "For Adam Smith, a city is in fact the result of agglomeration economies, with artisans and entrepreneurs settling in each other's vicinity to reduce transaction costs."

Smith also observes some convergence of wages and profits between the country and towns that had taken place in Britain over the preceding century. In doing so, he points out a centrifugal force that gradually emerges out of the over-accumulation of capital in urban areas:

“...industry has its limits like every other; and the increase of stock, by increasing the competition, necessarily reduces the profit. The lowering of profit in the town forces out stock to the country, where, by creating a new demand for country labour, it necessarily raises its wages. It then spreads itself, if I may say so, over the face of the land, and by being employed in agriculture is in part restored to the country, at the expense of which, in a great measure, it had originally been accumulated in the town." (145).

Here, Smith signals that as urbanisation and agglomeration grow, economies of agglomeration can at some point turn into diseconomies, with centrifugal prevailing over centripetal forces. As such, we could find here the seeds of geographical economics proposing an inverted U-shape trajectory of the concentration of economic activity (e.g. Grote, 2008). 


\section{Urban-regional geography and institutional development}

Smith points out that the existence of the village is a result of the division of labour between the farmer and the artisan. It is the social division of labour, in other words, that originally gives rise to the spatial division of labour (Dockès, 1969). Once links with the land are broken for artisans and merchants, these find it more useful for their daily needs to locate close to one another than be dispersed across the countryside. He writes:

\begin{abstract}
"Smiths, carpenters, wheel-wrights, and ploughwrights, masons, and bricklayers, tanners, shoemakers, and tailors [...] naturally settle in the neighbourhood of one another, and thus form a small town or village. The butcher, the brewer, and the baker soon join them, together with many other artificers and retailers [...] The town is a continual fair or market, to which the inhabitants of the country resort in order to exchange their rude for manufactured produce." (378).
\end{abstract}

In a historical account of the economic development in Europe from the fall of the Roman Empire to his day, Smith associates urban development with the advancement of capitalist institutions (chapter 3, book 3 ). He relates the formation and enlargement of cities with the establishment of judicial institutions independent from the influence of feudal lords, and with the enhancement of democratic representation. He goes on to show how the institutional progress of the city (its transition from feudalism to capitalism) is gradually transmitted to the country, thus enhancing political stability and law enforcement at the national level. In this part of his work, we find links to institutional economics and institutional economic geography (see e.g. Acemoglu \& Robinson, 2013; Martin, 2000).

Smith vividly describes a power game between the feudal lords, the king and the inhabitants of cities:

"The burghers naturally hated and feared the lords. The king hated and feared them too; but though perhaps he might despise, he had no reason either to hate or fear the burghers. Mutual interest, therefore, disposed them to support the king, and the king to support them against the lords. They were the enemies of his enemies, and it was his interest to render them as secure and independent of those enemies as he could. By granting them magistrates of their own, the privilege of making bye-laws for their own government, that of building walls for their own defence, and that of reducing all their inhabitants under a sort of military discipline, he gave them all the means of security and independency of the barons which it was in his power to bestow." (402).

Smith observes that some cities grew independent and turned into republics, as for instance in Italy and Switzerland; while others remained subordinated to the king, but with enhanced representation in national governance, as in France and England. In doing so, he touches upon the questions of political and economic centralisation, central to economic geography (see e.g. Rodríguez-Pose \& Ezcurra, 2010).

Subsequently, he discusses three ways in which urban growth led to national growth. First of all, through the market it opened for the output of agriculture. Second, through the purchases of uncultivated lands by the city's wealthy inhabitants. Third, through the introduction of "order and good government, and with them, the liberty and security of individuals" (412). For Smith, the latter is the most important, but least appreciated factor.

Smith observes that up until the growth and institutional progress of the city, feudal lords had a surplus produce which, in the absence of a large market, they were forced to consume within their estates, in practice spending it on the maintenance of numerous dependents, including servants, retainers and tenants. In exchange, the landlord's dependents were to offer him not only their services, but also their obedience, with the landlord acting as the judge in peace and the leader in war (415).

The way the growth of the city and the market changed this status quo was by offering landlords the option of spending their surplus on items of luxury. By reducing the numbers of dependents, landlords gradually gave away their authority over them. In turn, tenants became independent cultivators of the land, agreeing on long term leases with the landlords. With time, landlords became unable to influence the justice system and destabilise the country. Effectively, Smith 
describes here the emergence of conspicuous consumption, long before Veblen:

“...what all the violence of the feudal institutions could never have effected, the silent and insensible operation of foreign commerce and manufactures gradually brought about. [...] As soon $[\ldots]$ as [as the great proprietors] could find a method of consuming the whole value of their rents themselves, they had no disposition to share them with any other persons. For a pair of diamond buckles, perhaps, or for something as frivolous and useless, they exchanged the maintenance, or what is the same thing, the price of the maintenance of a thousand men for a year, and with it the whole weight and authority which it could give them." (418-9).

\section{Commercial centres}

In addition to reflecting on the scale of cities and their markets, as well as their physical location, Smith discusses the social and political composition of cities as crucial to their performance. In doing so, he draws the contours of an urban typology and hierarchy (Stull, 1986). For Smith, the idle part of the population, particularly the nobility, can adversely influence those employed in industry, and thus influence the broader character of a city. Indicatively:

"when [Edinburgh] ceased to be the necessary residence of the principal nobility and gentry of Scotland, it became a city of some trade and industry. [...] The inhabitants of a large village, it has sometimes been observed, after having made considerable progress in manufactures, have become idle and poor in consequence of a great lord having taken up his residence in their neighbourhood." (336).

According to Smith, the productivity of a city is also influenced by business temperament. Such temperament may differ from city to city, depending, among other factors, on the profitability of merchants' business (itself shaped by the degree of monopoly). For example, in his discussion of "mercantile manners" of Cadiz, Lisbon and Amsterdam, he describes the merchants of Cadiz and Lisbon as "magnificent lords", in contrast to the "attentive and parsimonious burghers of Amsterdam" (613).

Furthermore, while for Smith the inclination of merchants to re-invest their profits rather than spend them on consumption is a central success factor of commercial centres, he also pays attention to the geographical nature of their investment behaviour, signalling the existence of 'home bias', an important topic in contemporary economic and financial geography (see e.g. Wójcik, 2011). Smith writes that for the same profit a merchant will naturally prefer to invest at home, where he can keep closer oversight of his business. Beyond that, Smith elucidates how 'home bias' underpins the role of leading commercial centres in intermediating trade between distant cities and regions.

"The capital which an Amsterdam merchant employs in carrying corn from Konigsberg to Lisbon, and fruit and wine from Lisbon to Konigsberg, must generally be the one half of it at Konigsberg and the other half at Lisbon. No part of it need ever come to Amsterdam. The natural residence of such a merchant should either be at Konigsberg or Lisbon, and it can only be some very particular circumstances which can make him prefer the residence of Amsterdam. The uneasiness, however, which he feels at being separated so far from his capital generally determines him to bring part both of the Konigsberg goods which he destines for the market of Lisbon, and of the Lisbon goods which he destines for that of Konigsberg, to Amsterdam: and though this necessarily subjects him to a double charge of loading and unloading, as well as to the payment of some duties and customs, yet for the sake of having some part of his capital always under his own view and command, he willingly submits to this extraordinary charge; and it is in this manner that every country which has any considerable share of the carrying trade becomes always the emporium, or general market, for the goods of all the different countries whose trade it carries on." (454-5). 


\section{Financial geography}

In the preceding sections, we can already find instances where Smith touches on topics relevant to financial geography. In his association of speculative trades with great towns, for example, Smith highlights the roots of merchant banking, which in the twentieth century evolved into investment banking (Wójcik, 2012). Similarly, the above quote on the role of Amsterdam intermediating trade between the Baltic and North Atlantic, clearly hints at the role of the city as a financial centre. Smith's attention to Amsterdam becomes even more explicit in chapter 3 of book 4 of The Wealth, which includes a part labelled as Digression concerning Banks of Deposit, particularly concerning that of Amsterdam. There, Smith describes the workings of Amsterdam as a financial centre in significant detail. Kindleberger (1993: 49) called this section Smith's "famous digression" (though not so famous in practice as in edited versions of The Wealth this part is often entirely removed, e.g. see Smith, 2008 [1776]).

First, Smith observes that there is often uncertainty over the true value of a golden or silver coin, for instance due to the coin having been worn or clipped. While this uncertainty is of relatively little concern in a "great" country like England and France, it is felt more acutely in smaller states, where due to their size and location, the currency in circulation consists not only of their own coin, but also of the coins of neighbouring states with which their inhabitants have frequent exchanges. This observation applies primarily to city states, such as Genoa, Venice, Hamburg, as well as the city of Amsterdam. To cope with the uncertainty, those places introduced the idea of bank (i.e. paper) money, with its nominal value guaranteed by the state. This is what for Smith led to the establishment of the Bank of Amsterdam in 1609.

Smith, goes on to describe the sophisticated banking and trading system of Amsterdam at the time, related to the terms of trade of gold and silver, and the corresponding secondary market for certificates of bank deposit of bullion. Connecting these financial technicalities with Amsterdam as a financial centre, Smith describes the city as "the great warehouse of Europe for bullion" (484) and talks about the degree of trust the Bank of Amsterdam enjoys:
"At Amsterdam [...] no point of faith is better established than that for every guilder, circulated as bank money, there is a correspondent guilder in gold or silver to be found in the treasure of the bank. The city is guarantee that it should be so. The bank is under the direction of the four reigning burgomasters who are changed every year. Each new set of burgomasters visits the treasure, compares it with the books, receives it upon oath, and delivers it over, with the same awful solemnity, to the set which succeeds; and in that sober and religious country oaths are not yet disregarded." (486)

The above quote illustrates clearly the role of trust and governance in finance, topics of major significance in financial geography (Clark \& Monk, 2017; Thrift, 1994). Smith concludes the Digression by highlighting how lucrative the trading of bullion and currency has been not only for the Bank but also for the city of Amsterdam (487).

\section{Concluding remarks}

If we surveyed economic geographers in 2021 about their knowledge on Adam Smith and his Wealth of Nations, the answers would most likely revolve around the pin factory, the division of labour, and the invisible hand of the market. The objective of our article was to offer a taste of a closer reading of The Wealth and reflect on its relevance to contemporary economic geography. In doing so, we wanted to demonstrate the richness of Smith's approaches, concepts, and observations, which encompass a surprisingly broad range of geographical issues.

To start with, we argued that Smith approached the study of the economy in ways that should resonate with today's geography. If Smith was alive today, he would arguably be at home with interdisciplinary research, bottom-up inductive thinking, the value of fieldwork, and engagement with economic practitioners and practices. Geographical concepts, such as cities, towns, countryside and scale permeate his analysis. Smith recognised the significance of physical geography, not only in terms of proximity to sea and waterways, but also in terms of soil and climate. For him, urban scale was key to understanding markets, prices, wealth accumulation, trade and lobbying. 
Urban-rural relations were central to his insights on the development of institutions and the transition from feudalism to capitalism. He also investigated the social and political fabric of cities, offering ideas on urban typologies and hierarchies. Perhaps most surprisingly, The Wealth also considers the spatial nature of money and finance, including the role of information, trust, proximity, and the development of financial centres.

There is something stimulating, or at least provocative, to be found in The Wealth of Nations for many areas of economic geography, from labour, political and urban, through institutional, social and cultural, to evolutionary and financial. Clearly, this richness and diversity make the book worthy a place in an anthology of the discipline.

Acknowledgement The authors are grateful to Marica Frangakis, an anonymous reviewer and the editor for their useful comments on an earlier draft of the paper. The paper has benefited from funding from the European Research Council (European Union's Horizon 2020 research and innovation programme; grant agreement No. 681337). The article reflects only the authors' views and the European Research Council is not responsible for any use that may be made of the information it contains.

\section{Declaration}

\section{Conflict of interest None}

Open Access This article is licensed under a Creative Commons Attribution 4.0 International License, which permits use, sharing, adaptation, distribution and reproduction in any medium or format, as long as you give appropriate credit to the original author(s) and the source, provide a link to the Creative Commons licence, and indicate if changes were made. The images or other third party material in this article are included in the article's Creative Commons licence, unless indicated otherwise in a credit line to the material. If material is not included in the article's Creative Commons licence and your intended use is not permitted by statutory regulation or exceeds the permitted use, you will need to obtain permission directly from the copyright holder. To view a copy of this licence, visit http://creativecommons.org/licenses/by/4.0/.

\section{References}

Acemoglu, D., \& Robinson, J. (2013). Why nations fail. The origins of power, prosperity and poverty. London: Profile Books.

Arrighi, G. (2007). Adam Smith in Beijing: Lineages of the twenty-first century. London: Verso.
Brakman, S., Garretsen, H., \& van Marrewijk, C. (2012). The New introduction to geographical economics. Cambridge: Cambridge University Press.

Brewer, A. (1995). Rent and profit in the wealth of nations. Scottish Journal of Political Economy, 42(2), 183-200.

Clark, G. L., \& Monk, A. H. B. (2017). Institutional investors in global markets. Oxford: Oxford University Press.

Coe, N. M., Kelly, P. F., \& Yeung, H. W. C. (2013). Economic geography: A contemporary introduction (2nd ed.). Hoboken: Wiley.

Dicken, P., \& Lloyd, P. E. (1990). Location in space: Theoretical perspectives in economic geography (3rd ed.). New York: Harper Collins.

Dockès, P. (1969). L'espace Dans La Pensée Économique Du XVI Au XVIII Siècle. Paris: Flammarion. [in French].

Gee, A. (1981). The origin of rent in Adam Smith's Wealth of Nations: An anti-neoclassical view. History of Political Economy, 13(1), 1-18.

Grote, M. H. (2008). Foreign banks' attraction to the financial centre Frankfurt - an inverted 'U'-shaped relationship. Journal of Economic Geography, 8(2), 239-258.

Heilbroner, R. (1999). The worldly philisophers the lives, times and ideas of the great economic thinkers. New York: Touchstone.

Kindleberger, C. P. (1993). A Financial History of Western Europe (2nd ed.). Oxford: Oxford University Press.

Krugman, P. (1991). Geography and Trade. MIT Press.

Lee, R., \& Willis, J. (1997). Geographies of economies. London: Routledge.

Marshall, A. (1920). The principles of economics (8th ed.). London: Macmillan and Co.

Martin, R. (2000). Institutional approaches in economic geography. In Sheppard, E. and Barnes, T. (eds) A Companion to Economic Geography. Oxford: Blackwell.

Massey, D. (1984). Spatial divisions of labor: social structures and the geography of production. New York: Routledge.

Mellinger, A.D., Sachs, J.D., \& Gallup, J.L. (2000). Climate, coastal proximity, and development. In Clark, G.L., Gertler, M.S., \& Feldman, M.P. (eds) The Oxford Handbook of Economic Geography. Oxford: Oxford University Press.

Munck, B. D. (2016). Disassembling the city: A historical and an epistemological view on the agency of cities. Journal of Urban History, 43(5), 811-829.

Ponsard, C. (1983). History of spatial economic theory. Berlin: Springer.

Rodríguez-Pose, A., \& Ezcurra, R. (2010). Does decentralization matter for regional disparities? A cross-country analysis. Journal of Economic Geography, 10(5), 619-644.

Roncaglia, A. (2005). The wealth of ideas: A history of economic thought. Cambridge: Cambridge University Press.

Ross, I. S. (1995). The life of adam smith. Oxford: Clarendon Press.

Samuelson, P. (1978). The canonical classical model of political economy. Journal of Economic Literature, 16(4), 1415-1434.

Scott, A. J. (1986). Industrial organization and location: Division of labor, the firm, and spatial process. Economic Geography, 62(3), 215-231.

Scott, A. J. (1997). The cultural economy of cities. Essays on the geography of image-producing industries. London: Sage. 
Smith A (1976 [1776]) An Inquiry into the Nature and Causes of the Wealth of Nations. In The Glasgow edition of the works and correspondence of Adam Smith, vol. 1 and 2. Indianapolis: Liberty Fund reprint.

Smith, A. (2008). [1776]) An Inquiry into the Nature and Causes of the Wealth of Nations. Oxford: Oxford University Press.

Stull, W. (1986). The urban economics of adam smith. Journal of Urban Economics, 20, 291-311.

Sutherland, K. (2008). Editorial introduction and notes in the Wealth of Nations. In Smith A. (2008 [1776]) An Inquiry into the Nature and Causes of the Wealth of Nations. Oxford: Oxford University Press.

Thrift, N. (1994). On the social and cultural determinants of international financial centres: The case of the city of London. In Corbridge, S., Thrift, N., \& Martin, R. (eds) Money, Power And Space. Oxford: Blackwell.

Viner, J. (1927). Adam Smith and Laissez Faire. Journal of Political Economy, 35(2), 198-232.
Walker, R. (2020). Commentary on 2019 Roepke Lecture "War, Capitalism, and the Making and Unmaking of Economic Geographies." Economic Geography, 96(1), 23-30.

Winch D (2004) Smith, Adam. Oxford Dictionary of National Biography.

Wójcik, D. (2011). The global stock market: issuers, investors, and intermediaries in an uneven world. Oxford: Oxford University Press.

Wójcik, D. (2012). The end of investment bank capitalism? An economic geography of financial jobs and power. Economic Geography, 88(4), 345-368.

Wood, A., \& Roberts, S. (2011). Economic Geography. Places, Networks and Flows. New York: Routledge.

Publisher's Note Springer Nature remains neutral with regard to jurisdictional claims in published maps and institutional affiliations. 